\title{
Management of Students' Crisis in Higher Institutions of Learning in Nigeria
}

Onyike Margaret Odu

\author{
Department of Educational Foundations \\ College of Education, Oju, Benue State,Nigeria
}

\section{Doi:10.5901/mjss.2013.v4n8p91}

\section{Abstract}

This study was intended to investigate factors that characterized campus crisis and suggests way forward with the aim of maintaining crisis free institutions. Two null hypotheses were formulated and tested for the study. The results of this study suggest that: two reasons could be responsible for not meeting the demands of the students. First is the high population of students to match the available facilities, students' demands and the attitudes of some authorities who refuse to listen to students' request. Secondly, lack of essential facilities in campuses cause students' crisis in higher institutions of learning in Nigeria. Based on the findings, cultism, communication gap between authorities and students' representatives, hyper-patriotic youthful exuberance in deviating from behavioural norms of the society and students' home background are major causes of students' crisis in higher institutions in Nigeria.

\section{Introduction}

The current education reforms in education sector in Nigeria in the areas of planning, curriculum innovation and teacher education among others are management mechanism to revamp education industry to instill discipline in various institutions of learning. Government on her own side introduced the free education scheme and bursary award for students of tertiary institutions of learning. Government took these strides to enhance equal educational opportunities. The efforts of government not withstanding, there have been increase in students' crisis in almost all the higher institutions of learning especially in Nigerian universities. Crisis in Nigerian higher institutions is not a welcome development. Rather it is cankerworm, hydra headed, disturbing to parents/guardians and citizens of the nation. Akinade (1993) showcased students' crisis in Nigerian Universities between 1970 and 2005. The scenario is illustrated below:

a. Ahmadu Bello University, Zaria in 1970, the crisis was as a result of inadequate feeding and accommodation.

b. University of Ibadan in 1971, students requested for the removal of a catering officer, the incident resulted in the death of a student.

c. University of Ibadan in 1974, some students lost their lives for demanding the removal of catering officer.

d. Ahmadu Bello University, Zaria in 1978, over an increase in school fees which resulted into nationwide demonstration by University students.

e. Obafemi Awolowo University in 1981 over a beheaded undergraduate student (loss of life).

f. University of Nigeria, Nsukka 1981, over inadequate infrastructure.

g. Ahmadu Bello University, 1986 over high-handedness by the university authority.

h. University of Lagos, 1987 over imaginary white paper to expel a student leader as agent of unrest in ABU.

i. University of Jos, 1988 protest over government removal of oil subsidy. 
j. Obafemi Awolowo, Ife, Ilorin, Abeokuta Universities, 1991, over the refusal to yield to students demand.

k. Lagos State University 2002 - brutal murder of a union leader.

I. Ebonyi State University, 2004 crisis over bad road leading to Ishieke campus.

m. Lagos State University, 2002 - brutal murder of union leader.

Students' crisis in the institutions of learning constitutes a havoc as it often lead to temporary closure of the institution, boycott of lectures, suspension and expulsion of students and student leaders, loss of lives, damage of school properties, disruption of school administration and truncation in academic programmes of the university. (Sanya, 1981 and Aminu, 1988).

Cultism as one of the causes of students' crisis is described as an assemblage of people who share unconventional ideas, and beliefs and involve themselves in eccentric conduct and manifestation mostly shrouded in secrecy; carry out secret cult activities and membership, organization, rules and mode of operation are supposed to be unknown and unknowable to non-member cult (Umeh 2001 and Igodo 2002). Infighting and internal wrangling by cultists led to the formation of spinster groups such as Seadogs, Buccaneer confraternity, the Vikings, the Black Beret, the Daughters of Jezebel among others (Egwu, 2003). Impulsive desires for supremacy are among the reasons behind cult clashes, murder, maiming, rape, acts of sickening and barbarism in our institutions of higher learning (Umeh, 2001). Some of the special features of campus secret cults in Nigerian universities are nocturnal meetings held at odd places like cemeteries, hilltops or forests, knife and dagger pulling, gun drawing at non-members or members of opposed campus secret cults; torture, distinctive marks on the body; drinking human blood and others (Nwanze, 1991 and Igodo, 2002). Fetish practices, use of hand drugs, violence, ritual killing are modus operandi of secret cults. Onyeka (2002:34) reported that suspected, cultists once moved into the University of Nigeria, Nsukka (UNN) campus in a convoy of three cars "shooting endlessly at students said to be in the middle of an examination, sixteen of who were felled instantly. Mission done, the attackers then speed off to escape, fatally wounding two other persons bringing the death toll to eighteen. According to him, the attackers were unleashed by the Viking confraternity in revenge for an alleged killing of their two members by the Buccaneer. In another similar incidence in 2003, Ebonyi State University recorded the death of six students; massacre of five students union leaders of Obafemi Awolowo University, Ile-lfe in 1999 and the brutal murder of students union leader of Lagos State University in 2002 (Igodo 2002). Consequences of these nefarious act lead to indefinite closure of the institutions which the university authority cite as insecurity of lives and properties as reasons for the indefinite closure against cultism. Cult menaces in our institutions of higher learning are gaining momentum daily taking more dangerous dimensions and in fact, running a parallel government with the university authorities. Measures targeted at stemming the menace of cultism in institution of higher learning appear not yielding positive fruits.

Another fact that aggravate students' crisis in Nigeria universities is communication gap. Effective communication diffuses tension among students and authorities in the institution. Despite this fact, some authorities of Nigerian universities shut their administrative doors to students' complaints and grievances which may likely result to students registering some unacceptable social behaviour such as violent demonstration of 1981. Ezike (1993:6) stated some psychological consequences of shutting administrative doors on students' complaints and requests when he remarked, "they feel they are being processed by a system to which they strongly object but are powerless to challenge or change." When students are denied the opportunity of being part of policy making decision in related matters of their welfare they feel subjected and dehumanized. Students believe they should have significant voice in determining some issues patterning their welfare. When they ask to be heard and refused being heard and when legitimate channels are closed there is bound to be crisis. When students' body or representatives are excluded from participating in the deliberation on issues that significantly influence their educational objectives, a feeling of isolation and ostracism is created. Malevolent transformation of feeling of living among enemies is also created. This increases the probabilities of constant student-authority clashes in universities. Effective communication 
diffused tension between students and authorities in the institutions.

Youthful exuberance especially the negative characteristics is another serious issues that spark off students' crisis in our institutions of higher learning, social irrelevance of youth behaviour, confrontation, victims of intellectual arrogance, emotional instability are characteristics of adolescents which when overstretched results to disastrous consequences such as riots and demonstration (Okoye, 1983, Ufot 1980 and Refus 1980). Anowor (1983) observes that increase in physical characteristics of the adolescent often push them to over react. He compared their youthful exuberance to active volcano." That is, they cease every opportunity to display their strength and often do so in the wrong place, against wrong person as a result of misplaced aggression. Anowor's comparison is evidenced in a misplaced aggression when students of the Federal Government College, Otukpo in 2005 beat up an invigilator and set ablaze a car belonging to another invigilator because the invigilator insisted that students should write their first semester Mathematics examinations without cheating. Again, Ebonyi State University students in 2004 while protesting against poor condition of road leading to Ishieke campus, they organized and barricaded the express road leading to Abakaliki town, blocked traffic movement and destroyed goods running into millions of naira. In the words of Wale (1982:25) he attributed those negative attitudes to students' immaturity and with abundant energy and their belief that all scores should be settled violently. He reported "Moslem students in Kano municipality trooped out to destroy a Church. Their grouse was that the Christian Church was too close to a Mosque." Anything and everything is capable of arousing sentiments and wraths of students to warrant an unguided outpouring into the streets to protest concluded (Abdulahi 1991). Home background of students to some extent dictates the quality of students' behaviour at a stage in life. Students as products of the home their behaviour reflect the nature of their homes. Some undesirable behaviour of students directly or indirectly leads to students' crisis such as intimation, assault and insult, wanton destruction of property, participation in secret cults, drug offences, lesbianism, Anadi (1993) observed.

Students' crisis is worrisome to parents, government and even the students' themselves. Crisis in schools lead to closure, suspension disruption in academic calendar. Authorities cannot predict how long a semester or academic year could last (five or six years) depending on frequency of students' crisis. The situation is a serious challenge. The need to maintain crisis free system provided the motivation for the study. It was also the aim of the study to investigate factors that characterize campus crisis and suggest way forward.

The following two null hypotheses were formulated and tested for the study:

- $\mathrm{HO}_{1}$ : There is no significant difference between the opinion of male and female students on the causes of students' crisis.

- $\mathrm{HO}_{2}$ : There is no significant difference in the mean rating of students on management strategies of students' crisis.

The study whose scoped covered Ebonyi and Enugu State is limited to causes and management strategies of students' crisis. It is considered significant in many ways. There is no doubt that the study will provide database to authorities in tertiary institutions on students' crisis management, policymakers and guide future researchers.

\section{Method of Study}

A descriptive survey design was adopted for the study. Population of study comprised 60,800 students in tertiary institutions in Ebonyi and Enugu States. The sample for the study was 6,800 students selected through simple stratified random sampling technique. Data for the study were collected using a questionnaire titled Management of Students' Crisis (MSC). The questionnaire was validated by experts in educational administration/Management. A pilot study to determine the level of reliability was carried out on 20 students of Abia State University who were not part of the study within a time interval of two weeks using Cronbach reliability test that yielded an alpha value of $0.81(\mathrm{~N}=20)$. 
The instruments used for data collection were administered through research assistants. The data were analyzed using t-test statistical difference.

\section{Results and Discussion}

3.1 $\mathrm{HO}_{1}$. There is no significant difference between the opinion of male and female students on the causes of students' crisis in higher institution of learning.

Hypothesis 1 was tested using t-test. The result of the analysis is shown on table 1 below. t-test analysis showing differences expressed by male and female students.

\section{Table 1.}

\begin{tabular}{lllllll}
\hline Issues & Group & $\overline{\mathrm{X}}$ & SD & SD $\overline{\mathrm{X}}$ & Cal.t & Crit. t. \\
\hline Unfulfilled needs & Male & 3.05 & 0.58 & 0.58 & & \\
& Female & 3.00 & 0.59 & 0.139 & 1.45 & 1.99 \\
Cult activities & Male & 3.07 & 0.56 & & & \\
& Female & 3.06 & 0.60 & 0139 & 0.59 & 1.99 \\
Communication gap & Male & 2.74 & 0.58 & & & \\
& Female & 2.79 & 0.55 & 1.38 & 0.45 & 1.99 \\
\multirow{2}{*}{ Youthful exuberance } & Male & 2.48 & 0.43 & & & \\
\multirow{2}{*}{ Home factor } & Female & 2.50 & 0.62 & 0114 & 1.70 & 1.97 \\
& Male & 2.80 & 0.49 & & & \\
& Female & 2.79 & 0.51 & 122 & 1.61 & 1.97 \\
\hline
\end{tabular}

$\mathrm{P}<0.5$

According to the results presented in Table 1 above, all the calculated ' $t$ ' $(1.45,0.59 .0 .45,1.70$ and 1.61) are less than the critical ' $t$ ' (1.97). The null hypothesis is therefore upheld. This means that male and female students perception do not differ in their expression on the causes of students crisis in higher institution of learning.

\section{2 $\mathrm{HO}_{2}$. There is no significant difference in the mean rating of students on the management strategies of} students' crisis.

Hypothesis 2 was tested using t-test on management strategies of students crisis. The result of analysis is presented on table 2 below.

Table 2 showing the summary of t-test of difference of students in Ebonyi and Enugu States on management strategies. $P<0.5$

Table 2.

\begin{tabular}{lllllll}
\hline Issues & State & $\overline{\mathrm{X}}$ & SD & SD $\overline{\mathrm{X}}$ & Cal.t & Crit. t. \\
\hline Good governance & Ebonyi & 3.01 & 0.58 & 0.01 & & \\
& Enugu & 3.02 & 0.50 & 39 & 1.44 & 1.97 \\
Negotiation & Ebonyi & 3.04 & 0.56 & 0.001 & & \\
& Enugu & 3.06 & 0.56 & 56 & 1.43 & 1.92 \\
Free flow of & Ebonyi & 2.73 & 0.56 & 0.01 & & \\
Communication & Enugu & 2.71 & 0.58 & 36 & 1.45 & 1.97 \\
Professional & Ebonyi & 2.60 & 0.52 & 0.01 & & \\
Counselling & Enugu & 2.59 & 0.54 & 30 & 1.54 & 1.54 \\
Extra Curriculum & Ebonyi & 2.80 & 0.50 & 1.01 & & \\
& Enugu & 2.81 & 0.51 & 22 & 1.61 & 1.97 \\
\hline P $<0.5$ & & & & & &
\end{tabular}


According to the data shown above in table 2 at 0.05 level of significance, the calculated ' $t$ ' $(1.44,1.43,1.45$, 1.54 and 1.61) are less than the critical 't' value (1.97) it was therefore accepted as conflicting management strategies by the two States.

\section{Discussion of Findings}

On the student demands, two reasons could be responsible for not meeting their needs. First is the high population of students to match the available facilities, students' demand and the attitudes of some authorities who refuse to listen to students' requests. However, the finding of inadequate facilities agree with Onyecherelam (1983) who submitted that lack of essential facilities in campuses cause students' crisis in higher institutions of learning in Nigeria. One must not forget that hierarchy of needs (water, light, accommodation) must be met to attain a state of congruence because these are necessary for the survival of students on campus and most especially for the promotion of positive behaviour within the social environment.

Again, violent secret cult activities as another major cause of students' crisis was attributed to the intent to eliminate their rivals, control campus politics or students union government. Echezona (2001) described some of the cult members as academic never-do-well. The introduction of post screening test by university authorities is a good managerial technique that is likely going to stamp out or reduce cult activities, as academic-minded students will be selected for admission. Communication gap also influences students' crisis, the finding revealed that students in most cases lay their complaints through proper channels to air their grievances. Some major decision on students' crisis lay with the institution's Senate Council without been implemented. Added to this is lukewarm attitude of some of the school authorities to respond to students' complaints and sometimes complaints are treated with slash or silent reproach. University authorities should endeavour to be good listeners. Rioting and destruction of properties are ways of youth crisis (youthful exuberance). Most students are in their early adolescent stage with their attendant problems. Some choose to champion cases external to them. Instance of this is University of Nigeria, Nsukka (UNN) students' demonstration over 6-day electricity blackout in Nsukka. The finding of youthful exuberance agree with Okeke (1996) and Anowar (1993) who observed that adolescent possesses revolutionary and reformist zeal and can deviate from behavioural norms and even go extra miles in their pursuit to remedy some ills of the society.

\section{Management of Students' Crisis}

Students' crisis of any magnitude in higher institutions of learning in Nigeria is abnormal, dysfunctional and detestable. Crisis is an extreme situation of conflict to a point of extreme violence that is, threat to human security, fighting, death, injury, etc. (Gaya 2006). These are characteristics of students' crisis in our institution of learning as earlier itemized. But for Burton (1990) crisis can always be resolved, what the practitioners can do is to manage and regulate them. Some of the management strategies that school authorities should practice include:

a. Good-governance: Good governance is the process of crisis prevention through proactive measure of running the affairs of the institution in positive and progressive manner beneficial to students, listening to students' complaints, being transparent, democratic as opposed to autocratic and dictorial. Good-governance diffuse tensions and remove problems s they evolve (Gaya, 2006).

b. Clarification of communication: This takes the form of both parties avoiding harmful statement, looking for flexible 'shade of gray' solution, identifying conflict issues during negotiations. Otite (1990) remarked that use of appropriate communication skills and channels are crucial in crisis management. 
c. Exchange and sharing of accurate information can as well help to remove doubts and suspicions by students that their complaints are not being looked into by the school authority.

d. Negotiation: Negotiation as a structured process of dialogue between conflicting parties attempts to reach an agreement through joint decision. Students should not see this managerial skill, as "loopholes" therefore, should not be confrontational in their demands. Students should as much as possible compromise, that is make concessions in order to resolve crisis.

\section{Conclusion and Recommendations}

Based on findings, the study concludes that cultism, communication gap between authorities and students representative, hyper-patriotic youthful exuberance in deviating from behavioural norms of the society and students home background are major causes of students' crisis in higher institutions in Nigeria. The paper also concludes that good governance and dialogue are the most basic methods of crisis management and prevention. Again, indefinite closure of institution and expulsion of students as a yardstick against students' crisis should be sparely used as a corrective measure. The study recommends that:

1. School authorities should as much as possible observe transparency in their dealings with students, be proactive, listen to complaints and above all be democratic as opposed to autocracy in all matters affecting students' welfare.

2. All necessary information concerning students should be sold to them through the institutions house organ such as information bulletin newsletter and magazines. Information should be free and clarified; exchange and shared as it will remove doubts and suspicions. A free flow of information reduces misunderstanding or impulse and crisis emanating from communication gap.

3. Students should be less confrontational in the demands and it is only in extreme cases that suppression as management skill be used as the instrument of power and force to push away issues pertaining to students under the carpet or impose solution that is not sustainable.

4. The use of negotiation as a process of dialogue was also recommended. Conflicting parties should attempt to reach an agreement and take joint decision that will assist in resolving crisis.

5. School authorities should establish functional professional counselling units in all institutions of higher learning to provide counselling and psychological services to students to reduce behavioural activities that run counter to societal and institutional expectation.

6. Finally, responsible students should be nominated to serve in committees (e.g. disciplinary committee) and indirectly use them as informants to school authority to timely inform management when students plan riot or intending to take laws into their hands.

\section{References}

Abdullahi, A. (1991). Why 6-3-3-4 system is not working. Daily Times 12 March, 1991. P. 12.

Akinade, E.A. (1993). Guidance and counselling strategies for prevention in controlling.

Students Activities in Nigerian Tertiary Institutions in O. Animba, D. Denga and O. Omolabi, (eds.) Appraisal of students' unrest in Nigeria. Enugu: ABIC publishers.

Aminu, J.M. (1988). Only president can reopen universities. Daily Star x (390), 1 April, 20.

Anadi, G.C. (1993). The problem of indiscipline in Nigeria: The home factor in $O$.

Animba, D. Denga and O. Omolabi (eds.). Appraisal of students' unrest in Nigeria. Enugu: ABIC publishers,

Anowor, O.O. (1993). Adolescence and its implication for improvement of students.

Discipline in O. Animba, D. Denga, and O. Omolabi (eds). Appraisal of students unrest in Nigeria: Enugu: ABIC publishers.

Burton, J.W. (1990). Conflict resolution and prevention. London: Macmillan.

Echezona, I. (2001). Curbing secret cults-related crisis in Nigerian Universities.

A.U. Akubue and D. Enyi (eds.). Crisis and challenges in developing countries. Ibadan: Wisdom Publishers Ltd. 
Egwu, E. (2003). Foresight: Towards exposing and eradicating cult and other social vices on campus. Lagos: Bravo Nominees Ltd.

Ezike, H.O. (1993). Root cause and remedies of indiscipline in Nigerian universities in O. Aniomba, D. Denga and O. Omolabi (eds.) Appraisal of students' unrest in Nigeria: Enugu: ABIC Publishers.

Gaya, S.B. (2006). The methods of conflict resolution and transformation in Gaya, S.B. (ed.). Introduction to peace and conflict studies in West Africa. Ibadan: Spectrum Books Limited.

Igodo, C. (2002). Campaign against cultism and drug abuse among youths in Nigeria. Enugu: Magnet Business.

Nwanze, S. (1991). Unveiling the secret of secret societies in campuses. National Concord, Lagos. 18 $8^{\text {th }}$ April, 1991. P. 16 $-18$.

Okoye, N.N. (1993). Psychological techniques for handling campus indiscipline in our institutions of higher learning in O. Animba, D. Denga and O. Omolabe (eds.) appraisal of students unrest in Nigeria. Enugu: ABIC publishers.

Okeke, V.U. (1996). Factors affecting students' crisis as perceived by the staff and students of UNN. Unpublished M.Ed. Thesis. October 1996.

Olanrewaju, K. (2003). I have lost a gem. The Cornet Newspaper (Lagos) $28^{\text {th }}$ August, 2003. P.3

Onyecheralam, C.A. (1983). A study of cases of students' unrest as perceived by students in selected secondary schools in Imo State. Unpublished M.Ed. Thesis June 1983.

Onyeka, B.V. (2002). Morning Madness at UNN. The Guardian (Lagos) 22nd June, 2002. P. 24.

Otite, O. (1999). On conflict, their resolution, transformation and management. In O. Otite (ed.). Community conflicts in Nigeria Ibadan: Spectrum Books Ltd.

Rufus, I. (1980 May, 21). Dealing with students' unrest. Daily Times. 1(314), 10.

Sanya, O.A. (1981, May 2). Decade students' unrest. Sunday Concord. 1 (413), 3.

The Guardian (2002). Cultism and violence on our campuses. The Guardian (Lagos) March 2002. P. 22

Ufot, O.A. (1980). Students part, riot and demonstration. The Calabar Education: A journal for education practitioners and thinker in Africa 1(5) $35-38$.

Obi, E. (1997). Communication and management of organization behaviour in A.N.

Ndu, L.O. Ocho and O. Okeke (eds.) Dynamic of educational administration and management. Awka: Makes publishers. Umeh, E.D. (2001). Tertiary institution in Nigeria: haven or coven. Enugu: Pan African publishers.

Wale, A. (1982). Forty-four confirmed dead in Kano and Kaduna. Daily Times (Lagos) $4^{\text {th }}$ November, 1982. P. 25. 
